\title{
Pengaruh Tingkat Pendapatan dan Jumlah Anggota Keluarga Terhadap Konsumsi Gas Elpiji Pada Sektor Rumah Tangga
}

\author{
Tunjung Genarsih
}

Institut Agama Islam Negeri Ponorogo, Indonesia ginargin28@gmail.com

\begin{abstract}
Abstrak: Pandemi Covid-19 mempunyai dampak di berbagai bidang salah satunya di bidang ekonomi terutama terhadap pendapatan masyarakat Indonesia. Penelitian ini membahas pengaruh pendapatan dan jumlah anggota keluarga terhadap konsumsi gas elpiji pada sektor rumah tangga selama masa pandemi Covid-19. Metode penelitian dengan kuesioner digunakan pada penelitian ini. Responden merupakan rumah tangga biasa di wilayah Kabupaten Pacitan. Berdasarkan hasil pengolahan data dengan menggunakan regresi linear berganda diperoleh persamaan $Y=0.539+0.193 X_{1}+0.451 X_{2}$ yang berarti bahwa setiap satu satuan skor konsumsi gas elpiji akan dipengaruhi oleh $X_{1}$ (pendapatan) sebesar 0.193 dan $X_{2}$ (jumlah anggota keluarga) sebesar 0.451, dapat disimpulkan bahwa jumlah anggota keluarga mempunyai pengaruh yang lebih besar terhadap konsumsi gas elpiji. Koefisien determinasi sebesar $51.4 \%$ dan sisanya $48.6 \%$ dijelaskan oleh variabel lain yang belum diteliti. Berdasarkan uji hipotesis diperoleh secara parsial pendapatan berpengaruh signifikan terhadap konsumsi gas elpiji dengan $t_{\text {hitung }}=4.899$ lebih besar dari $t_{\text {tabel }}=1.664$. Jumlah keluarga berpengaruh secara signifikan dengan nilai $t_{\text {hitung }}$ sebesar 6.129 lebih besar dari nilai $\mathrm{t}_{\text {tabel }}=1.664$. Sedangkan secara simultan diperoleh $\mathrm{F}_{\text {hitung }}=41.802>\mathrm{F}_{\text {tabel }}=3.11$. Hal ini berarti hipotesis yang diajukan bahwa pendapatan dan jumlah anggota keluarga berpengaruh terhadap konsumsi gas elpiji dapat diterima. Hasil ini berdampak praktis terhadap pengaturan konsumsi rumah tangga.
\end{abstract}

Kata Kunci: Tingkat pendapatan, jumlah anggota keluarga, konsumsi

\begin{abstract}
The Covid-19 pandemic has an impact in various fields, one of which is in the economic sector, especially on the income of the Indonesian people. This study discusses the effect of income and number of family members on LPG consumption in the household sector during the Covid-19 pandemic. The research method with a questionnaire was used in this study. Respondents are ordinary households in the Pacitan Regency. Based on the results of data processing using multiple linear regression, $Y=0.539+0.193 X_{1}+0.451 X_{2}$ an equation is obtained which means that each unit score of LPG gas consumption will be influenced by X1 (income) of 0.193 and X2 (number of family members) of 0.451 , it can be concluded that the number of family members has a more influence big on LPG gas consumption. The coefficient of determination is $51.4 \%$ and the remaining $48.6 \%$ is explained by other variables that have not been studied. Based on the hypothesis test, it was obtained that income partially had a significant effect on $L P G$ consumption with $t_{\text {count }}=4,899$ greater than $t_{\text {table }}=1,664$. The number of families has a significant effect on the value of $t_{\text {count }}$ of 6,129 , which is greater than the value of $t_{\text {table }}=1,664$. Meanwhile, simultaneously obtained $F_{\text {count }}=41,802>F_{\text {table }}=3.11$. This means that the hypothesis that the income and number of family members have an effect on LPG consumption can be accepted. These results have practical implications for household consumption regulation.
\end{abstract}

Keywords: Income, number of family, consumption

\section{PENDAHULUAN}

Adanya peningkatan jumlah kasus Covid-19 mendorong pemerintah menetapkan berbagai kebijakan strategis guna membatasi kegiatan sosial semua lapisan masyarakat. 
Kebijakan tersebut berdampak praktis terhadap kebiasaan, gaya, pola, dan budaya kerja, baik di lingkungan pemerintahan maupun swasta, dan rumah tangga. Selain itu, pandemi Covid19 berdampak terhadap bidang ekonomi pada sektor pendapatan masyarakat Indonesia. . Kondisi ini dianggap logis karena adanya pembatasan sosial guna mencegah penyebaran Covid-19 memaksa para konsumen lebih banyak beraktivitas di rumah dan pelaku usaha mengurangi jumlah pekerja dan atau produksi. Kondisi ini melanda semua wilayah di Indonesia, termasuk kabupaten Pacitan. Pada Agustus 2020, ada sebanyak 357.946 orang penduduk yang bekerja sedangkan 8,34 ribu lainnya menganggur. Jumlah penduduk yang mengganggur ini bertambah 5.05 ribu orang dibanding tahun 2019. Tingkat partisipasi angkatan kerja di Pacitan pada Agustus 2019 0.91\% naik menjadi 2.28\% pada Agustus 2020. Hal ini diduga sebagai akibat dari pandemi Covid-19 selain lapangan pekerjaan yang sulit dicari banyak dari masyarakat yang awalnya bekerja di kota-kota besar terpaksa harus pulang ke desa-desa, sementara itu di desa tidak tersedia lapangan pekerjaan hal ini secara langsung berdampak pada meningkatnya pengangguran (BPS, 2020). Meningkatnya pengangguran ini tentu akan mengakibatkan penurunan pendapatan.

Sebanyak 84\% masyarakat merasakan adanya penurunan pendapatan (Setiawan, 2020). Namun di sisi lain besarnya pendapatan secara signifikan memengaruhi tingkat penggunaan energi_(Estiri et al., 2013). Peningkatan konsumsi energi rumah tangga sejalan dengan kenaikan pendapatan rumah tangga (Pitts \& Ashby, 2011). Hal tersebut sejalan dengan hasil penelitian sebelumnya bahwa dampak pandemi Covid-19 juga memengaruhi kehidupan individu dan masyarakat pada bidang sosial dan pangan (Juntra et al., 2020). Melalui kebijakan work from home (WFH) berakibat pembelajaran di semua jenjang pendidikan juga dilakukan dari rumah masing-masing (study from home) (Handarini \& Wulandari, 2020). Hal ini logis menyebabkan anggota keluarga yang biasanya di luar rumah untuk bekerja dan sekolah lebih banyak menghabiskan waktunya di rumah. Ini mengakibatkan pola konsumsi masyarakat berubah. Masyarakat lebih senang memasak dan makan di rumah karena ada mandat stay at home, social distancing, PSBB dll (Nababan, 2020). Sehingga, semakin banyak jumlah anggota keluarga jumlah penggunaan gas elpiji dan pengeluaran semakin meningkat (Pranadji et al., 2010). Fakta tersebut didukung dengan laporan PT Pertamina bahwa selama pandemi Covid-19 terjadi kenaikan penggunaan gas elpiji bersubsidi. Konsumsi harian gas elpiji $3 \mathrm{~kg}$ naik mencapai 22.117 metrik ton dibandingkan sebelumnya sebesar 21.927 metrik ton (Pertamina, 2020).

Dengan demikian penelitian ini bertujuan untuk mengetahui pengaruh pendapatan terhadap konsumsi gas elpiji, pengaruh jumlah anggota keluarga terhadap konsumsi gas elpiji, dan pengaruh secara simultan pendapatan dan jumlah anggota keluarga terhadap konsumsi gas elpiji selama masa pandemi Covid-19. Konteks pandemi Covid-19 pada 
variabel konsumsi gas elpiji menjadi pembeda dari penelitian terdahulu utamanya yang berkaitan dengan variabel pendapatan.

\section{TINJAUAN LITERATUR}

\section{Konsumsi}

Konsumsi merupakan penggunaan barang dan jasa, seperti pakaian, makanan, minuman, rumah, peralatan rumah tangga, kendaraan, peralatan hiburan, media cetak dan produk elektronik, jasa konsultasi hukum, jasa konsultasi kesehatan, pembelajaran/ kursus, dll (Hidayat, 2010). Konsumsi juga dapat diartikan sebagai kegiatan memanfaatkan, menghabiskan kegunaan suatu barang dan jasa guna memenuhi kebutuhan demi menjaga kelangsungan hidup (Arif, 2010). Menurut Keynes tingkat konsumsi ditentukan oleh tingkat pendapatan, sehingga belanja konsumsi sendiri merupakan bagian dari pendapatan (Samuelson \& Nordhaus, 2004) . Konsumsi dipengaruhi oleh beberapa faktor antara lain faktor ekonomi seperti pendapatan rumah tangga, kekayaan rumah tangga, jumlah barangbarang konsumsi, tingkat bunga, dan perkiraan masa depan. Faktor lain yang memengaruhi konsumsi adalah faktor demografi seperti jumlah penduduk dan komposisi penduduk (Rahardja \& Manurung, 2008). Sehingga dapat disimpulkan berdasarkan beberapa definisi konsumsi di atas bahwa secara umum konsumsi merupakan kegiatan yang melibatkan perorangan maupun kelompok dalam memanfaatkan, menggunakan, maupun menghabiskan barang dan jasa dalam rangka memenuhi kebutuhan demi kelangsungan hidupnya. Penelitian ini selanjutnya fokus pada konsumsi barang rumah tangga berupa gas elpiji.

\section{Pendapatan}

Menurut ilmu ekonomi, pendapatan mengacu pada jumlah maksimum yang dikonsumsi seseorang dengan mengharapkan kondisi yang sama seperti keadaan semula pada akhir periode (Huda, 2009). Selanjutnya pendapatan juga merupakan total penerimaan yang diperoleh pada periode tertentu (Reksoprayitno, 2004). Pendapatan sendiri berkaitan dengan tingkat pengeluaran masyarakat atau pengeluaran konsumsi (Nurmanaf \& Susilowati, 2000). Biasanya tingkat pendapatan berbanding lurus dengan tingkat konsumsi, jika tingkat pendapatan meningkat maka kemampuan ruamh tangga untuk melakukan kegiatan konsumsi juga meningkat (Rahardja \& Manurung, 2008). Penelitian ini selanjutnya fokus pada pendapatan rata-rata per bulan rumah tangga selama pandemi covid-19.

\section{Jumlah Anggota Keluarga}

Keluarga adalah kumpulan dari dua orang atau lebih yang hidup dengan keterikatan emosional dimana setiap individu memiliki perannya masing-masing yang merupakan bagian dari keluarga (Suprajitno, 2003). Besarnya jumlah konsumsi dipengaruhi oleh jumlah anggota keluarga, sehingga semakin besar jumlah anggota keluarga akan menambah pengeluaran konsumsi (Todaro, 2000). Adapun yang menjadi bagian dari jumlah anggota keluarga adalah semua anggota keluarga yang tinggal dan makan dari satu dapur bersama 
dengan kelompok penduduk tenaga kerja (Mantra, 2003). Penelitian selanjutnya fokus pada jumlah anggota keluarga yang ditanggung kepala keluarga.

\section{METODE PENELITIAN}

Penelitian ini dilakukan di wilayah kabupaten Pacitan dengan subjek penelitian adalah rumah tangga biasa (non pelaku usaha). Objek dari penelitian ini adalah pendapatan dan jumlah anggota keluarga terhadap tingkat konsumsi gas elpiji selama masa pandemi.

Metode penelitian dalam penelitian ini adalah metode kuantitatif deskriptif. Data primer dalam penelitian ini merupakan data yang dikumpulkan melalui kuesioner yang disebarkan oleh peneliti dan peneliti lapangan. Kuesioner_disebarkan secara online melalui grup-grup media sosial yang potensial dalam memberikan jawaban sesuai dengan tujuan penelitian. Metode online dipilih karena menimbang situasi pembatasan sosial masih berlaku. Guna meningkatkan kredibilitas data maka penyebaran kuesioner dibatasi pada grup WhatsApp yang beranggotakan kepala dan ibu rumah tangga biasa atau bukan pelaku usaha. Dengan demikian populasi dalam penelitian ini adalah seluruh rumah tangga biasa yang berdomisili di wilayah kabupaten Pacitan. Teknik sampling yang digunakan dalam penelitian ini adalah cluster random sampling dan ukuran sampel yang diperoleh sebanyak 82 rumah tangga.

Penelitian ini menggunakan teknik analisis data regresi linear berganda. Hipotesis diuji dengan uji secara simultan ( $F$-test) dan uji secara parsial ( $t$-test) untuk mengetahui pengaruh antar variabel penelitian. Prasyarat analisis yang digunakan adalah uji normalitas digunakan untuk mengetahui apakah data berdistirbusi normal atau tidak. Selanjutnya adalah uji multikolinearitas, multikolinearitas timbul disebabkan oleh satu atau lebih variabel independen yang merupakan kombinasi linear pasti atau mendekati pasti dari variabel independen lainnya. Jika terdapat multikolinearitas pasti maka koefisien regresi dari variabel independen tersebut tidak dapat ditentukan dan variansinya bernilai tak hingga. Jika multikolinearitasnya mendekati pasti, koefisien regresinya dapat ditentukan tapi nilai variansinya sangat besar sehingga tidak dapat memberikan penaksiran secara akurat. Selanjutnya adalah uji heterokedastisitas, uji ini digunakan untuk melihat apakah variansi model regresi bebas dari kesalahan pengganggu untuk variabel independennya. Uji selanjutnya adalah autokorelasi, uji ini digunakan untuk melihat apakah ada korelasi antar variabel independen. Terakhir adalah uji linearitas, uji ini digunakan untuk mengetahui apakah model regresi yang digunakan sudah benar dan fungsi yang digunakan linear atau tidak. Hasil analisis regresi linear berganda berupa persamaan berikut:

$$
\hat{Y}=a+b_{1} \cdot X_{1}+b_{2} X_{2}+\ldots+e
$$

dimana:

$\hat{Y}=$ Konsumsi 
$a=$ Konstanta

$b_{1}, b_{2}=$ Koefisien regresi

$X_{1}=$ Variabel pendapatan

$X_{2}=$ Variabel jumlah anggota keluarga

\section{HASIL DAN PEMBAHASAN}

\section{Deskriptif Variabel Penelitian}

Berdasarkan hasil uji statistik deskriptif variabel bebas pengaruh pendapatan dan jumlah anggota keluarga terhadap tingkat konsumsi gas elpiji pada sektor rumah tangga diperoleh data sebagai berikut:

Tabel 1. Deskriptif Data pada Ketiga Variabel Penelitian

\begin{tabular}{lccccc}
\hline \multicolumn{1}{c}{ Variabel } & $\boldsymbol{N}$ & Maximum & Minimum & Mean & $\begin{array}{c}\text { Std. } \\
\text { Deviation }\end{array}$ \\
\hline Pendapatan & 82 & 5.5 & 0.3 & 2.36 & 1.493 \\
$\begin{array}{l}\text { Jumlah Anggota } \\
\quad \text { Keluarga }\end{array}$ & 82 & 8 & 2 & 3.67 & 1.055 \\
$\begin{array}{l}\text { Tingkat Konsumsi } \\
\text { M }\end{array}$ & 82 & 8 & 1 & 3.04 & 1.222 \\
\hline
\end{tabular}

Sumber: Data Primer (Data Diolah)

Tabel 1 menunjukkan bahwa pendapatan terendah rumah tangga adalah Rp. 300.000 sedangkan pendapatan tertinggi senilai Rp. 5.500.000. Berdasarkan jumlah anggota keluarga dapat dilihat bahwa jumlah anggota keluarga paling sedikit adalah 2 dan yang paling banyak adalah 8. Sedangkan jika dilihat dari tingkat konsumsi penggunaan gas elpiji dalam satu bulan yang paling banyak adalah 8 tabung gas dan yang paling sedikit adalah 1 tabung gas ukuran $3 \mathrm{~kg}$.

\section{Uji Multikolinearitas}

Tujuan uji multikolinearitas ini adalah untuk melihat apakah pada model regresi ditemukan adanya korelasi antar variabel independen atau tidak. Berdasarkan hasil uji multikolinearitas terhadap variabel penelitian diperoleh data sebagai berikut:

Tabel 2. Uji Multikolinearitas

\section{Coefficients}

Model Collinearity Statistics




\begin{tabular}{|c|c|c|}
\hline & Tolerance & $V I F$ \\
\hline Pendapatan & 0.971 & 1.030 \\
\hline \multicolumn{3}{|c|}{ Jumlah Anggota } \\
\hline Keluarga & 0.971 & 1.030 \\
\hline
\end{tabular}

Sumber: Data Primer (Data Diolah)

Tabel 2 menunjukkan nilai Tolerance pendapatan dan jumlah anggota keluarga lebih dari 0.10 sebesar 0.971 , sedangkan nilai VIF pendapatan dan jumlah anggota keluarga kurang dari 10 yaitu sebesar 1.030 sehingga berdasarkan nilai Tolerance maupun VIF dapat disimpulkan bahwa tidak terjadi multikolinearitas terhadap variabel penelitian.

\section{Uji Heterokedastisitas}

Uji asumsi heterokedastisitas digunakan untuk melihat apakah model regresi terdapat ketidaksamaan varians residual dari persamaan satu ke persamaan lain.

Berdasarkan hasil uji heterokedastistas yang telah dilakukan diperoleh data sebagai berkut:

Gambar 1. Hasil Uji Heterokedastisitas

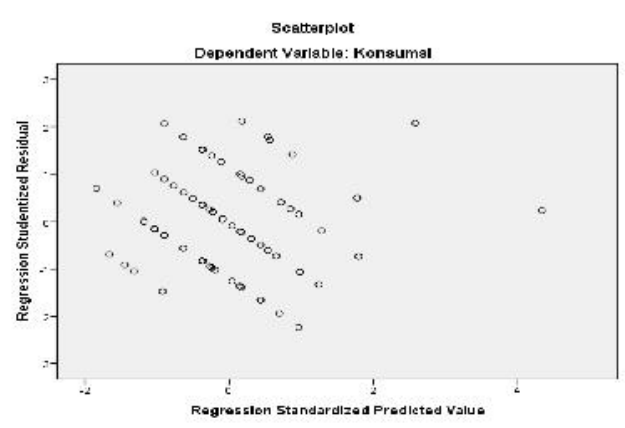

Data grafik scatterplot menunjukkan bahwa titik-titik menyebar acak baik di atas maupun di bawah angka nol sumbu Y. Hal ini berarti bahwa regresi tidak memiliki masalah heterokedastisitas. Jadi dapat disimpulkan bahwa model pada penelitian ini memenuhi syarat untuk menjadi model yang baik.

\section{Uji Autokorelasi}

Uji aoutokorelasi digunakan untuk melihat apakah terjadi korelasi antar observasi dalam satu variabel. Jika terjadi autokrelasi maka varian sampel tidak dapat menggambarkan varian populasi. Sehingga model regresi yang baik disyaratkan tidak terjadi masalah autokorelasi. Berdasarkan uji autokorelasi didapatkan data sebagai berikut:

Tabel 3. Hasil Uji Autokorelasi

Model Summary 


\begin{tabular}{cc}
\hline Model & $\begin{array}{c}\text { Durbin- } \\
\text { Watson }\end{array}$ \\
\hline 1 & 2.228
\end{tabular}

Sumber: Data Primer (Data Diolah)

Tabel 3 menunjukkan nilai Durbin Watson sebesar 2.228 dengan $\mathrm{k}=2$ dan $\mathrm{N}=82$ diperoleh nilai $\mathrm{dU}=1.6913$ dan nilai $\mathrm{dL}=1.6488$. Nilai Durbin Watson $2.095>1.7241$ sehingga dapat disimpulkan regresi tidak mengalami masalah autokorelasi positif. Sedangkan dengan melihat nilai $4-d U=4-1.6913=2.3087$ dimana nilainya lebih diperoleh $1.6913<2.228<2.3087$ sehingga dapat disimpulkan regresi tidak mengalami masalah autokorelasi negatif. Sehingga berdasarkan uji autokorelasi penelitian ini memenuhi syarat untuk menjadi model regresi yang baik.

\section{Uji Linearitas}

Uji linearitas dilakukan untuk mengetahui apakah model regresi spesifikasinya sudah benar atau tidak dan fungsinya linear atau tidak. Berdasarkan hasil pengolahan data diperoleh hasil uji linearitas untuk variabel pendapatan dan tingkat konsumsi gas elpiji sebagai berikut:

Tabel 4. Hasil Uji Linearitas Konsumsi Gas Elpiji dan Pendapatan

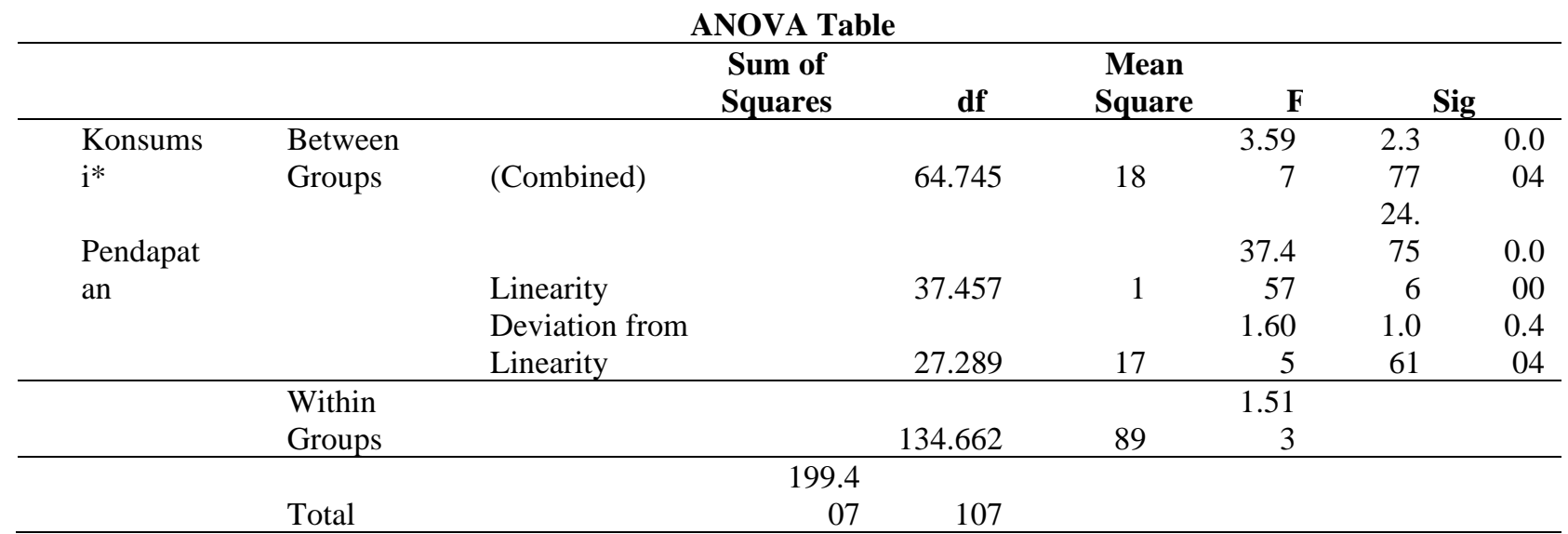

\section{Sumber: Data Primer (Data Diolah)}

Tabel 4 menunjukkan nilai deviasi dari linearitas sebesar $0.404>0.05$ hal ini berarti bahwa ada hubungan linear antara variabel pendapatan dan variabel konsumsi gas elpiji. Selanjutnya akan dilihat hasil uji linearitas untuk variabel konsumsi dengan variabel jumlah anggota keluarga. Data hasil olah data uji linearitas disajikan pada tabel berikut:

Tabel 5. Hasil Uji Linearitas Konsumsi Gas Elpiji dan Jumlah Anggota Keluarga 


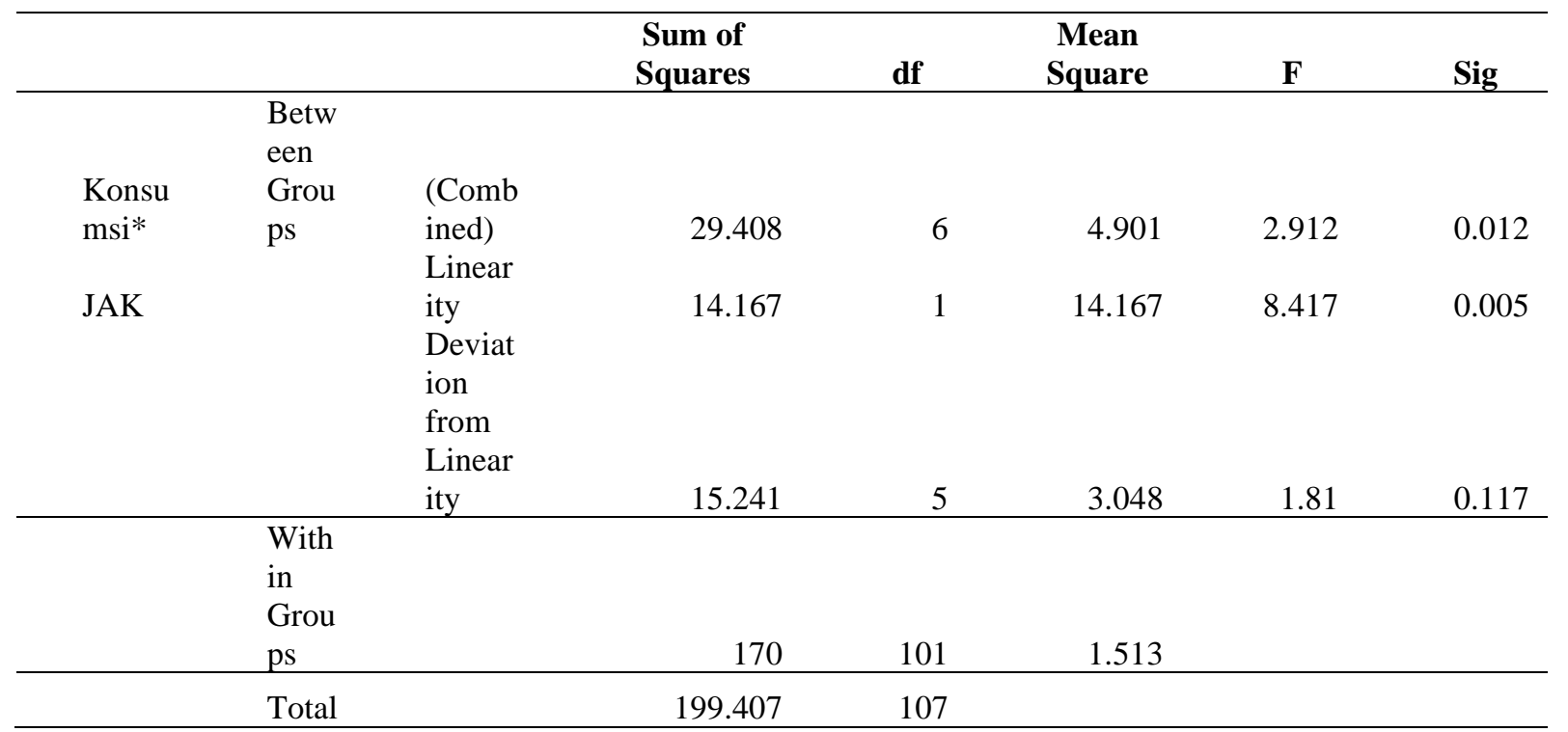

Sumber: Data Primer (Data Diolah)

Tabel 5 menunjukkan nilai deviasi dari linearitas sebesar $0.117>0.05$ hal ini berarti bahwa ada hubungan linear antara variabel jumlah anggota keluarga dan variabel konsumsi gas elpiji. Berdasarkan hasil uji linearitas maka dapat dikatakan bahwa model regresi merupakan model yang benar spesifikasinya dan persamaan dalam bentuk linear.

\section{Uji Normalitas}

Uji normalitas dilakukan untuk melihat apakah dalam model regresi variabel independen, dependen atau keduanya berdistribusi normal atau tidak. Model regresi yang baik adalah yang memiliki distribusi data normal atau mendekati normal.

Kriteria pengambilan keputusan model regresi dikatakan berdistribusi normal jika titiktitik ploting menyebar di sekitar garis diagonal. Normalitas juga dilihat dengan uji Kolmogorov-Smirnov dengan melihat nilai signifikansinya.

Gambar 2. Hasil Uji Normalitas

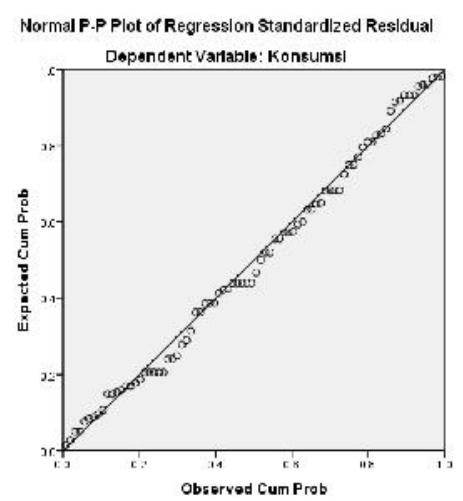

Berdasarkan tampilan dari pada gambar 2 di atas grafik normal p-plot of regresson standardized residual terlihat bahwa titik-titik menyebar di sekitar garis diagonal. Grafik ini menunjukkan bahwa model regresi tidak menyalahi aturan normalitas. Sehingga dapat dikatakan bahwa data berdistribusi normal. Sedangkan berdasarkan uji Kolmogorov-Smirnov diperoleh data sebagai berikut:

Tabel 6. Hasi Uji Kolmogorov-Smirnov 
One Sample Kolmogorov-Smirnov Test

\begin{tabular}{llr}
\hline & & $\begin{array}{r}\text { Unstandardized } \\
\text { Residual }\end{array}$ \\
\hline $\mathrm{N}$ & & 82 \\
Normal Parameters & $\begin{array}{l}\text { Mean } \\
\text { Std. }\end{array}$ & 0.000 \\
& Deviaton & 0.852 \\
Most Extreme & Absolute & 0.065 \\
Diffrences & Positive & 0.065 \\
& Negative & -0.051 \\
Tes Statistic & & 0.065 \\
Asymp. Sg. (2-tailed) & & 0.200 \\
\hline
\end{tabular}

Sumber: Data Primer (Data Diolah)

Berdasarkan nilai Asymp.Sg. (2-tailed) pada tabel 6 sebesar 0.200 yang nilainya lebih besar dari 0.05 data penelitian berdistribusi normal. Sehingga berdasarkan kedua uji dapat disimpulkan penelitian memenuhi syarat untuk menjadi model regresi yang baik karena persyaratan normalitas sudah terpenuhi.

\section{Koefsien Determinasi}

Nilai koefisien determinasi digunakan untuk melihat seberapa besar pengaruh yang diberikan variabel independen terhadap variabel dependen. Berikut ini merupakan luaran nilai koefisien determinasi:

Tabel 7. Luaran Koefisien Determinasi

Model Summary

\begin{tabular}{ccccc}
\hline & & R & Adjusted $\boldsymbol{R}$ & $\begin{array}{c}\text { Std. Error of the } \\
\text { Square }\end{array}$ \\
Model & $\boldsymbol{R}$ & Square & Estimate \\
\hline 1 & 0.717 & 0.514 & 0.502 & 0.862 \\
\hline
\end{tabular}

Sumber: Data Primer (Data Diolah)

Berdasarkan data pada tabel 6 diperoleh nilai $R$ Square sebesar 0.514 mempunyai arti bahwa tingkat konsumsi gas elpiji dipengaruhi oleh variabel pendapatan dan jumlah anggota keluarga sebesar $51.4 \%$. Sedangkan sisanya $48.6 \%$ dipengaruhi oleh variabel lain yang belum diteliti.

\section{Analisis Regresi Berganda}

Berdasarkan hasil analisis regresi berganda diperoleh data sebagai berikut: 
JoIE: Journal of Islamic Economics | Tunjung Genarsih

Tabel 8. Hasil Analisis Regresi Berganda (Coeffcients)

\begin{tabular}{|c|c|c|c|c|c|c|}
\hline \multicolumn{2}{|c|}{ Model } & \multicolumn{2}{|c|}{$\begin{array}{c}\text { Unstandardzed } \\
\text { Coeffcients }\end{array}$} & \multirow{2}{*}{$\begin{array}{l}\text { Standadzed } \\
\text { Coefficients }\end{array}$} & \multirow[t]{2}{*}{$t$} & \multirow[t]{2}{*}{ Sig. } \\
\hline & & $B$ & Std. Error & & & \\
\hline \multirow[t]{5}{*}{1} & (Constant) & 0.539 & 0.313 & & 1.722 & 0.089 \\
\hline & Pendapatan & 0.193 & 0.039 & 0.433 & 4.899 & 0.000 \\
\hline & Jumlah & & & & & \\
\hline & Anggota & & & & & \\
\hline & Keluarga & 0.451 & 0.074 & 0.542 & 6.129 & 0.000 \\
\hline
\end{tabular}

Sumber: Data Primer (Data Diolah)

Tabel 8 menunjukkan persamaan regresi berganda $Y=0.539 X_{1}+0.193 X_{2}+0.451$. Berdasarkan persamaan regresi tersebut didapatkan nilai $\mathrm{a}=0.539$ yang berarti apabila variabel pendapatan dan jumlah anggota keluarga bernilai 0 maka besarnya tingkat konsumsi gas elpiji adalah 0.539. Sedangkan nilai koefisien regresi variabel pendapatan sebesar 0.193 menunjukkan bahwa jika variabel pendapatan meningkat satu poin maka konsumsi gas elpiji akan meningkat sebesar 0.193 dengan syarat variabel lain nilainya konstan. Koefisien regresi variabel jumlah anggota keluarga sebesar 0.451 menunjukkan bahwa jika variabel jumlah anggota keluarga menngkat satu poin maka konsumsi gas elpiji akan meningkat sebesar 0.451 dengan syarat variabel lain bernilai konstan. Berdasarkan data ini dapat dilihat bahwa koefisien regresi yang paling tinggi adalah koefisien jumlah anggota keluarga. Sehingga dapat disimpulkan bahwa jumlah anggota keluarga mempunyai pengaruh yang lebih tinggi dibandingkan dengan variabel pendapatan. Hal ini sesuai dengan pendapat Rahardja \& Manurung (2008) yang mengatakan bahwa besarnya pendapatan berbanding lurus dengan besarnya pengeluaran, semakin tinggi pedapatan maka pengeluaran atau konsumsi juga akan semakin naik.

Uji t

Uji t digunakan untuk menguji hipotesis penelitian secara parsial. Dalam penelitian ini akan dilihat pengaruh secara parsial variabel pendapatan terhadap konsumsi gas elpiji dan pengaruh secara parsial variabel jumlah anggota keluarga terhadap konsumsi gas elpiji. Berdasarkan hasil analisis data diperoleh data sebagai berikut:

Tabel 9: Hasil Analisis Data Uji t (Coeffcients)

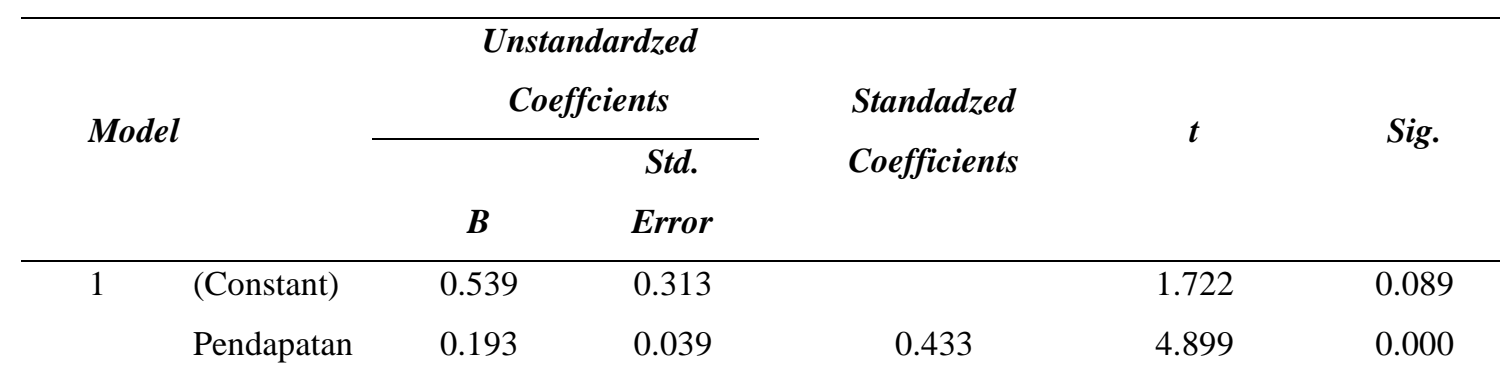


Jumlah

Anggota

Keluarga

$0.451 \quad 0.074$

0.542

6.129

0.000

Sumber: Data Primer (Data Diolah)

Tabel 9 menunjukkan nilai thitung untuk variabel pendapatan sebesar 4.899 lebih besar dari nilai tabel sebesar 1.664 dan nilai signifikansi 0.000 lebih kecil dari 0.05 hal ini berarti bahwa variabel pendapatan berpengaruh signifikan terhadap tingkat konsumsi gas elpiji pada sektor rumah tangga di wilayah kabupaten Pacitan. Hal ini sesuai dengan pendapat Keynes yang mengatakan bahwa tingkat konsumsi ditentukan oleh besarnya tingkat pendapatan (Samuelson \& Nordhaus, 2004). Sedangkan nilai thitung untuk variabel jumlah anggota keluarga sebesar 6.129 lebih besar dari nilai tabel $=1.664$ dan nilai signifikansi 0.000 lebih kecil dari 0.05 maka dapat disimpulkan bahwa variabel jumlah anggota keluarga berpengaruh signifikan terhadap tingkat konsumsi gas elpiji pada sektor rumah tangga di wilayah kabupaten Pacitan. Hal ini sesuai dengan pendapat Todaro (2000) yang mengatakan bahwa jumlah konsumsi keluarga dipengaruhi oleh jumlah atau banyaknya anggota keluarga, sehingga semakin besar jumlah anggota keluarga akan menambah pengeluaran konsumsi.

\section{Uji F}

Uji F digunakan untuk melihat pengaruh secara simultan variabel pendapatan dan jumlah anggota keluarga terhadap tingkat konsumsi gas elpiji. Berdasarkan analisis diperoleh data sebagai berikut:

Tabel 10. Hasil Uji F (ANOVA)

\begin{tabular}{|c|c|c|c|c|c|c|}
\hline \multirow{2}{*}{\multicolumn{2}{|c|}{ Model }} & \multicolumn{5}{|c|}{ Mean } \\
\hline & & Sum of Squares & $d f$ & Square & $F$ & Sig \\
\hline \multirow[t]{3}{*}{1} & Regression & 62.156 & 2 & 31.078 & 41.802 & 0.000 \\
\hline & Residual & 58.734 & 79 & 0.743 & & \\
\hline & Total & 120.890 & 81 & & & \\
\hline
\end{tabular}

Sumber: Data Primer (Data Diolah)

Berdasarkan luaran pada tabel 10 diperoleh nilai signifikansi sebesar $0.000<0.05$ dan nilai $\mathrm{F}_{\text {hitung }}=41.802>\mathrm{F}_{\text {tabel }}=3.11$. Hal ini berarti secara bersama-sama variabel pendapatan dan jumlah anggota keluarga berpengaruh simultan terhadap konsumsi gas elpiji pada sektor rumah tangga di wilayah kabupaten Pacitan. Sesuai dengan pendapat Rahardja \& Manurung (2008) yang mengatakan bahwa konsumsi dipengaruhi oleh beberapa faktor diantaranya ekonomi seperti pendapatan rumah tangga kemudian faktor lain yang memengaruhi konsumsi jumlah penduduk dan komposisi penduduk. Mengacu pada hasil di atas logis jika setiap penambahan anggota keluarga akan menambah jumlag konsumsi rumah tangga, begitu juga dengan besarnya pedapatan, semakin besar tingkat pendapatan akan mendorong keluarga untuk memenuhi kebutuhan setiap anggota keluarga. 


\section{KESIMPULAN}

Berdasarkan hasil pengolahan data menunjukkan hipotesis diterima. Secara parsial pendapatan berpengaruh signifikan terhadap konsumsi gas elpiji pada sektor rumah tangga dan secara parsial jumlah keluarga berpengaruh secara signifikan. Berdasarkan hasil pengolahan data secara simultan pendapatan dan jumlah anggota keluarga berpengaruh signifikan terhadap konsumsi gas elpiji pada sektor rumah tangga. Hasil penelitian ini berimplikasi terhadap rumah tangga dalam pengaturan pendapatan dan pengeluaran untuk konsumsi rumah tangga.

Selanjutnya dalam penelitian ini tentu masih banyak yang harus dikembangkan. Terlebih dalam penelitian ini periode waktunya hanya dilakukan di masa pandemi covid-19 yang cukup membatasi kegiatan penelitian. Penelitian selanjutnya dapat dikembangkan dengan menambah variabel-variabel lain yang belum ada pada penelitian ini dan menambah jumlah responden agar hasil penelitian lebih terukur

\section{REFERENSI}

Arif, M. N. R. A. (2010). Teori mikro ekonomi suatu perbandingan ekonomi Islam dan ekonomi konvensional. Kencana Prenada Media Group.

Estiri, H., Gabriel, R., Howard, E., \& Wang, L. (2013). Different Regions, Differences in Energy Consumption: Do Regions Account for the Variability in Household Energy Consumption? SSRN Electronic Journal, 134. https://doi.org/10.2139/ssrn.2323248

Handarini, O. I., \& Wulandari, S. S. (2020). Pembelajaran Daring Sebagai Upaya Study From Home (SFH) Selama Pandemi Covid 19. Jurnal Pendidikan Administrasi Perkantoran, 8(3), 496-503.

Hidayat, M. (2010). Pengantar ekonomi syariah. Zikrul MEdia Group.

Huda, N. dkk. (2009). Ekonomi makro islam. Prenada Media Group.

Juntra, L., Program, U., Gizi, S., Kemenkes, P., Jalan, K., \& Tallo -Kupang, P. A. (2020). Gaya Hidup Mayarakat Nusa Tenggara Timur Dalam Menghadapi Pandemi Corona Virus Disease 19 (Covid-19). Jurnal Kesehatan Masyarakat, 7(1), 34-40. https://ojs.uniska-bjm.ac.id/index.php/ANN/article/view/2994

Mantra, I. D. . (2003). No Title. Pustaka Raja.

Nababan, H. (2020). The New Trends of Food in Indonesia and Its Challenges. Https://Cfns.Ugm.Ac.Id/2020/10/06/Tantangan-Dan-Tren-Makanan-Di-IndonesiaBerubah/.

Nurmanaf, A., \& Susilowati, S. (2000). Struktur kesempatan kerja dan kaitannya dengan pendapatan dan penngeluaran rumah tangga pedesaan. Prosiding Perspektif Pembangunan Pertanian Dan Pedesaan Dalam Era Otonomi Daerah, 88-93.

Pitts, A., \& Ashby, R. (2011). No TitlA Study of the Relationships between Income, Energy 
JoIE: Journal of Islamic Economics | Tunjung Genarsih

Consumption and Home Insulation Installation. UK Energy Research Centre Conference: Energy and People: Futures, Complexity and Challenge.

Pranadji, D., Djamaludin, M., \& Kiftiah, N. (2010). Analisis perilaku penggunaan lpg pada rumah tangga di kota Bogor. Jurnal Ilmu Keluarga Dan Konsumen, 3(2), 173-183.

Rahardja, P., \& Manurung, M. (2008). Pengantar ilmu ekonomi (mikroekonomi \& makroekonomi) (3rd ed.). Fakultas Ekonomi UI.

Reksoprayitno. (2004). Sistem ekonomi dan demokrasi ekonomi. Bina Grafika.

Samuelson, P. ., \& Nordhaus, W. . (2004). Ilmu mikroekonomi (17th ed.). PT Media Global Edukasi.

Setiawan, S. R. . (2020). Survei: 84 persen masyarakat akui pendapatan turun karena corona.

Suprajitno. (2003). Asuhan keperawatan keluarga: aplikasi dan praktik. Buku Kedokteran EGC.

Todaro, M. (2000). Pembangunan ekonomi di dunia ketiga. Erlangga. 